Review

\title{
Oxygen Selective Membranes for Li-Air $\left(\mathrm{O}_{2}\right)$ Batteries
}

\section{Owen Crowther * and Mark Salomon *}

MaxPower, Inc., 141 Christopher Lane, Harleysville, PA 19438, USA

* Author to whom correspondence should be addressed;

E-Mails: Owen.Crowther@MaxPowerInc.com (O.C.); Mark.Salomon@MaxPowerInc.com (M.S.); Tel.: +1-215-256-4575; Fax: +1-215-256-1674.

Received: 17 April 2012 / Accepted: 7 May 2012 / Published: 11 May 2012

\begin{abstract}
Lithium-air (Li-air) batteries have a much higher theoretical energy density than conventional lithium batteries and other metal air batteries, so they are being developed for applications that require long life. Water vapor from air must be prevented from corroding the lithium (Li) metal negative electrode during discharge under ambient conditions, i.e., in humid air. One method of protecting the Li metal from corrosion is to use an oxygen selective membrane (OSM) that allows oxygen into the cell while stopping or slowing the ingress of water vapor. The desired properties and some potential materials for OSMs for Li-air batteries are discussed and the literature is reviewed.
\end{abstract}

Keywords: lithium-air battery; oxygen selective membrane; oxygen permeability; ambient discharge

\section{Introduction}

While metal-air batteries based on zinc, magnesium and aluminum anodes are well developed technologies [1], the development of lithium-air (Li-air) batteries had remained elusive until the breakthrough study by Abraham and Jiang [2]. The attractiveness of Li-air batteries compared to other common battery systems is due to the promise of greatly improved energies and capacities for Li-air batteries. Theoretical energies and capacities for selected electrochemical systems were calculated [3-5] from critically evaluated Gibbs energies of formation data from [6], and the results are given in Table 1. The increasing number of publications on Li-air batteries is indicative of the importance of these batteries for future applications to electric vehicles (EVs) and hybrid electric vehicles (HEVs), portable electronics, unattended remote sensors and other applications that have recently been 
reviewed by Christensen et al. [7] and by Crowther and Salomon [8]. For the present review, we focus on new approaches under development at MaxPower and others relating to oxygen selective membranes (OSMs) for the air electrode of a primary nonaqueous, Li-air battery. Figure 1 shows two Li-air designs presently under development at MaxPower.

Table 1. Theoretical specific energy and capacity comparisons for selected battery systems.

\begin{tabular}{llll}
\hline Metal-air system & $\begin{array}{l}\text { OCV } \\
(\mathbf{V})\end{array}$ & $\begin{array}{l}\text { Specific energy } \\
(\mathbf{W h} / \mathbf{k g})\end{array}$ & $\begin{array}{l}\text { Specific capacity } \\
\text { (mAh/g) }\end{array}$ \\
\hline $2 \mathrm{Li}+1 / 2 \mathrm{O}_{2} \rightarrow \mathrm{Li}_{2} \mathrm{O}$ (aprotic organic sln) & 2.913 & $11,248 *$ & 3,862 \\
$\mathrm{Li}+1 / 2 \mathrm{O}_{2} \rightleftharpoons 1 / 2 \mathrm{Li}_{2} \mathrm{O}_{2}$ (aprotic organic sln) & 2.959 & $11,425 *$ & 3,862 \\
$2 \mathrm{Li}+1 / 2 \mathrm{O}_{2}+\mathrm{H}_{2} \mathrm{SO}_{4} \rightleftharpoons \mathrm{Li}_{2} \mathrm{SO}_{4}+\mathrm{H}_{2} \mathrm{O}$ & 4.274 & $2,046 *$ & 479 \\
$2 \mathrm{Li}+1 / 2 \mathrm{O}_{2}+\mathrm{H}_{2} \mathrm{O} \rightleftharpoons 2 \mathrm{LiOH}$ & 3.446 & $5,789 *$ & 1,681 \\
$2 \mathrm{Li}+\mathrm{H}_{2} \mathrm{O}($ seawater$) \rightarrow 2 \mathrm{LiOH}+1 / 2 \mathrm{H}_{2}$ & 2.512 & $9,701 * *$ & 3,862 \\
$\mathrm{Al}+0.75 \mathrm{O}_{2}+1.5 \mathrm{H}_{2} \mathrm{O} \rightleftharpoons \mathrm{Al}(\mathrm{OH})_{3}$ & 2.701 & $4,021 *$ & 1,489 \\
$\mathrm{Mg}+1 / 2 \mathrm{O}_{2}+\mathrm{H}_{2} \mathrm{O} \rightleftharpoons \mathrm{Mg}(\mathrm{OH})_{2}$ & 2.756 & $3,491 *$ & 1,267 \\
$\mathrm{Zn}+1 / 2 \mathrm{O}_{2} \rightleftharpoons \mathrm{ZnO}$ & 1.650 & $1,353 *$ & 820 \\
$\mathrm{x} 6 \mathrm{C}+\mathrm{LiCoO} \rightleftharpoons x \mathrm{xiC}_{6}+\mathrm{Li}_{1-\mathrm{x}} \mathrm{CoO}_{2}$ (organic) & $\sim 4.2$ & $420 * * *$ & $139 * * *$ \\
\hline
\end{tabular}

* The molecular mass of $\mathrm{O}_{2}$ is not included in these calculations because $\mathrm{O}_{2}$ is freely available from the atmosphere and therefore does not have to be stored in the battery or cell; ** The molecular mass of $\mathrm{H}_{2} \mathrm{O}$ is not included since it is freely available from seawater $(\mathrm{pH} 8.2)$ and does not have to be stored in the battery. *** Based on $\mathrm{x}=0.5$ in $\mathrm{Li}_{1-\mathrm{x}} \mathrm{CoO}_{2}$.

Figure 1. Designs for Li-air batteries. In the protected anode approach shown at the left, the lithium anode is protected by a glass-ceramic disc (membrane) which is hermetically sealed to the anode. This solid-state glass-ceramic is a $\mathrm{Li}^{+}$conductor impervious to water. In the protected cathode design shown at the right, the glass-ceramic solid-state membrane is removed and instead a flexible OSM is attached to the surface of the air electrode facing the atmosphere.
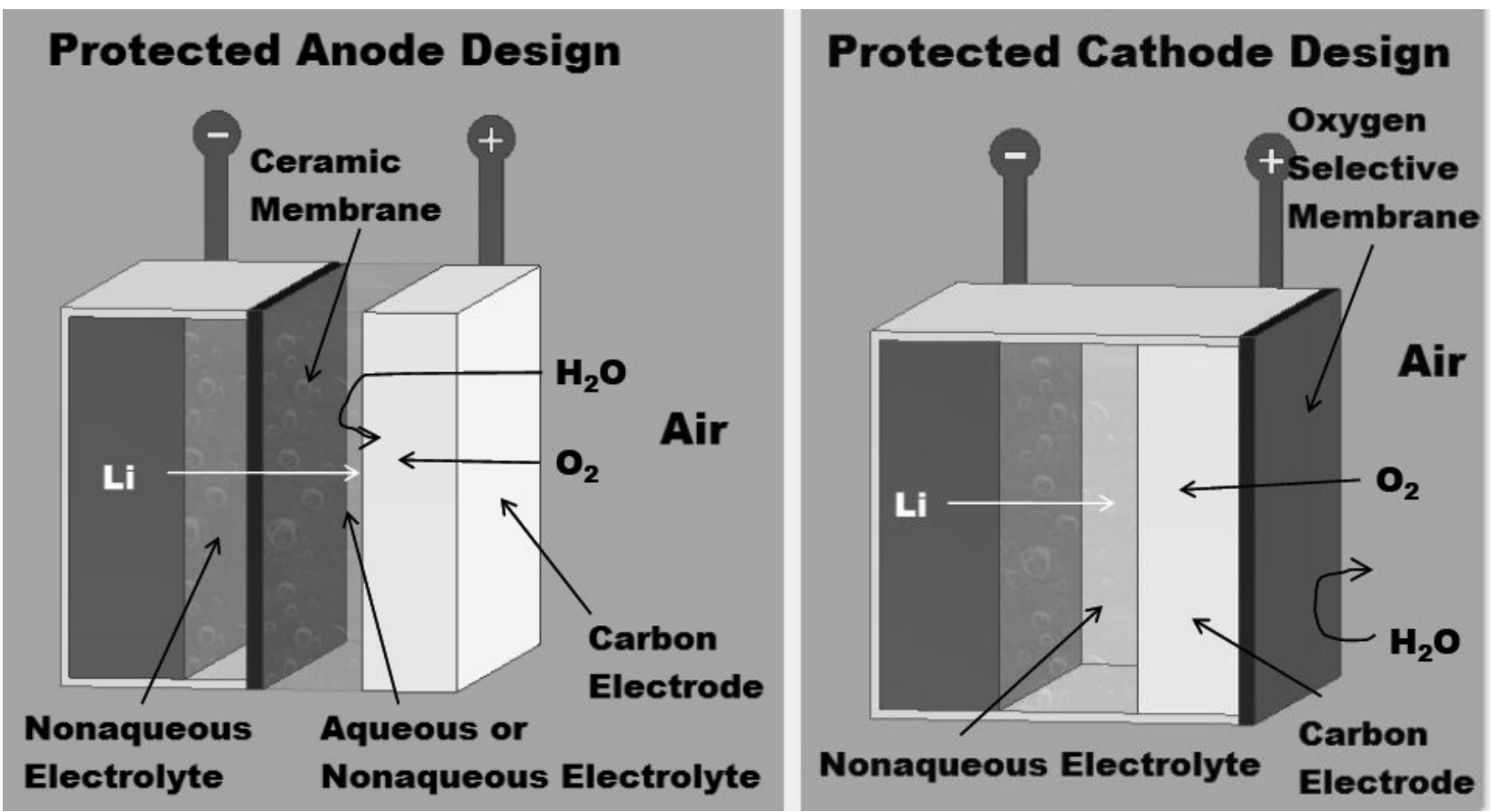
The design for the protected anode model is dependent upon a lithium ion $\left(\mathrm{Li}^{+}\right)$conducting membrane which is impervious to water, and for both aqueous and nonaqueous electrolyte solutions, present research for this membrane is focusing on $\mathrm{Li}^{+}$conducting glass ceramics such as those developed by O'Hara Corporation [9-11] and its use in practical systems as originally proposed by Visco et al. [12]. Li-air cells based on the protected anode are well suited for application to both primary and rechargeable batteries, but technical problems relating to membrane chemical and mechanical stability, high cost and high resistivity are presently key areas of R\&D as reviewed recently by Christensen et al. [7] and Crowther and Salomon [8]. In addition, secondary Li-air batteries face the problem of Li dendrite formation during charging that will limit cell cycle life and safety [13]. For the present review, we focus on nonaqueous primary Li-air cells based on the protected cathode design that use OSMs as shown in Figure 1.

\section{Properties of Oxygen Selective Membranes}

The protected cathode design for a Li-air power source is best suited for primary cells and batteries using nonaqueous electrolyte solutions. An OSM for Li-air cells and batteries should possess the following desired properties that are discussed in greater detail below.

1. High $\mathrm{O}_{2}$ permeability;

2. No water vapor permeability;

3. No electrolyte solvent permeability;

4. No carbon dioxide $\left(\mathrm{CO}_{2}\right)$ permeability for secondary applications.

\subsection{High $\mathrm{O}_{2}$ Permeability}

Basic materials for use as OSM must be capable of dissolving large amounts of $\mathrm{O}_{2}$ (oxygen) and possess a high rate at which $\mathrm{O}_{2}$ can diffuse through these membranes. The permeability, $P_{\mathrm{O}_{2}}$, or transmission rate of $\mathrm{O}_{2}$ (OTR) through a barrier is dependent upon the solubility of $\mathrm{O}_{2}$ in the membrane and the rate of diffusion of $\mathrm{O}_{2}$ through the membrane, and is defined by

$$
P=S D
$$

where $D$ is the diffusion coefficient $\left[\mathrm{cm}^{2} \mathrm{~s}^{-1}\right]$ and $S$ is the solubility coefficient (not solubility). The solubility coefficient can be determined experimentally or from known values of Henry's Law constants, $K_{H, c p}$, defined as

$$
K_{H, c p}=c / p
$$

where $c$ is the concentration [mole $\mathrm{L}^{-1}$ ] and $p$ is the partial pressure of $\mathrm{O}_{2}[\mathrm{~mm} \mathrm{Hg}$ or Pa]. For most nonaqueous electrolyte solutions used in Li-air cells, $K_{H, c p}$ data for $\mathrm{O}_{2}$ are not available, but for a number pure nonaqueous solvents, $K_{H, c p}$, values and solubilities have been compiled by Battino [14,15] and Dias et al.[16]. The units for permeability, $P$, normalized for membrane thickness is, from Equation (1).

$$
P=\mathrm{cm}^{3} \text { (gas) } \mathrm{cm} \mathrm{cm}^{-2} \mathrm{~s}^{-1} \mathrm{~mm} \mathrm{Hg}^{-1}
$$


where $\mathrm{cm}^{3}$ (gas) is actually a molar quantity evaluated at standard temperature and pressure that can determined from $K_{H, c p}$ data. The units for $P$ are often given in Barrer which is defined by

$$
1 \text { Barrer }=10^{-11} \mathrm{~cm}^{3} \text { (gas) } \mathrm{cm} \mathrm{cm}^{-2} \mathrm{~mm} \mathrm{Hg}^{-1}
$$

The oxygen flux, $j_{O_{2}}$, can be directly related to maximum (limiting) current density, $i_{m a x}$, assuming the oxygen reduction reaction (ORR) is mass transfer limited by $\mathrm{O}_{2}$ transport through the OSM. The maximum (limiting) current density due to $\mathrm{O}_{2}$ diffusion for an air cathode protected by an OSM is highly dependent on the magnitude of $P$, and below we show that membranes where $P<100$ Barrer are not practical for a commercial Li-air cell. In view of the limited amount of data required to calculate permeability values from Equations (1-3), values of $P$ can easily be determined experimentally using a barrier testing instrument such as the one available from MOCON, Inc.

Abraham and Jiang [2] originally hypothesized that the oxygen reduction reaction (ORR) in nonaqueous electrolyte solutions proceeds by the following mechanisms during discharge of a Li-air battery.

$$
\begin{gathered}
4 \mathrm{Li}^{+}+\mathrm{O}_{2}+4 \mathrm{e}^{-} \rightarrow 2 \mathrm{Li}_{2} \mathrm{O} \\
2 \mathrm{Li}^{+}+\mathrm{O}_{2}+2 \mathrm{e}^{-} \leftrightarrow \mathrm{Li}_{2} \mathrm{O}_{2}
\end{gathered}
$$

Several recent publications, reviewed by Christensen et al. [6], demonstrated that the solvent actually reacts during ORR for electrolytes that use alkyl carbonates as solvents to form products with limited reversibility, namely lithium carbonate and lithium alkyl carbonates, and not the desired lithium peroxide. However, ORR in ether-based electrolyte solutions will proceed predominantly according to Equation (6).

The maximum current density due to diffusion of $\mathrm{O}_{2}$ through the membrane is based on the oxygen flux, $j_{\mathrm{O}_{2}}$, which can be related to permeability by the following equation.

$$
j_{O_{2}}=P_{O_{2}} \frac{\Delta p}{t}
$$

where $\Delta p$ is the partial pressure gradient of $\mathrm{O}_{2}$ across the membrane and $t$ is the membrane thickness. The partial pressure of $\mathrm{O}_{2}$ in air is $\sim 160 \mathrm{~mm} \mathrm{Hg}$ and will be 0 in the air electrode assuming $\mathrm{O}_{2}$ is the limiting reactant so $\Delta p=160 \mathrm{~mm} \mathrm{Hg}$. The flux of $\mathrm{O}_{2}$ through the membrane can also be improved by decreasing the thickness of the membrane. However, membrane fabrication techniques typically limit the thickness to 10-25 $\mu \mathrm{m}$ before pinhole defects are present. Also, decreasing the thickness of the membrane will also increase the permeation of water vapor and electrolyte solvent. The maximum current density is given by

$$
i_{\text {max }}=n F j_{O_{2}}
$$

where $n$ is the equivalents of electrons reacted per mole of oxygen and $F$ is Faraday's constant $\left(=10^{5} \frac{C}{\text { equive } e^{-}}\right)$. From Equations (5) and (6), $n$ is equal to 4 for $\mathrm{Li}_{2} \mathrm{O}$ formation and 2 for $\mathrm{Li}_{2} \mathrm{O}_{2}$ formation. McCloskey et al. [17] experimentally determined $\mathrm{n}=2.6$ for the ORR in alkyl carbonates due to the reaction of the electrolyte solvent with $\mathrm{Li}^{+}$and $\mathrm{O}_{2}$ to form lithium carbonate and lithium alkyl carbonates. Figure 2 shows the effect of $\mathrm{O}_{2}$ permeability in Barrer on maximum current density 
for a $1 \mu \mathrm{m}$ thick membrane. The data were derived using the Equations $(3,4,7,8)$. This assumes the air window and air electrode have equal geometric areas. The maximum current density for a Li-air battery limited by $\mathrm{O}_{2}$ transport through an OSM of any thickness can be determined by dividing the $i_{\max }$ for a given permeability obtained from Figure 2 by the actual thickness in microns of the OSM. For example, a membrane that is $1 \mu \mathrm{m}$ thick with a permeability of 500 Barrer would have a limiting current density of approximately $68 \mathrm{~mA} \mathrm{~cm}{ }^{-2}$ based on $\mathrm{Li}_{2} \mathrm{O}_{2}$ formation. The limiting current density is $1.4 \mathrm{~mA} \mathrm{~cm}^{-2}$ for the same membrane if it is $50 \mu \mathrm{m}$ thick.

Figure 2. Effect of $\mathrm{O}_{2}$ permeability on maximum current density, $i_{\max }$, for a $1 \mu \mathrm{m}$ thick OSM. Black circle points correspond to $\mathrm{n}=2$, red triangle points correspond to $\mathrm{n}=2.6$, green square points correspond to $\mathrm{n}=4$ equivalent $\mathrm{e}^{-}$per mole of $\mathrm{O}_{2}$.

$$
\mathrm{O}_{2} \text { permeability * } 160 \mathrm{~mm} \mathrm{Hg} / \mathrm{mol} \mathrm{O}_{2} \mu \mathrm{m} \mathrm{cm}^{-2} \mathrm{~s}^{-1}
$$

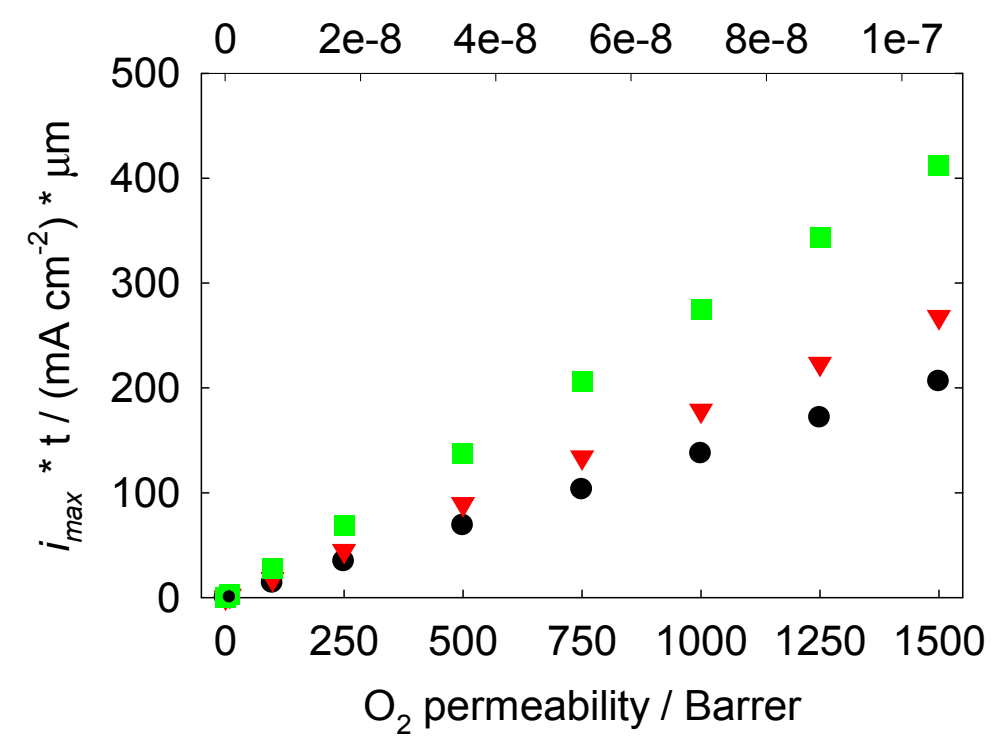

\subsection{No Water Vapor Permeability}

The three important gases in dry air are $\mathrm{N}_{2}(78 \mathrm{o} / \mathrm{v}), \mathrm{O}_{2}(21 \mathrm{o} / \mathrm{v})$ and $\mathrm{CO}_{2}(0.4 \mathrm{o} / \mathrm{v})$, water being variable at $\sim 1-4 \mathrm{o} / \mathrm{v}$ depending upon relative humidity. Materials considered for membranes will vary in ability to dissolve and transmit these gases. A solid, gel or immobilized liquid is required to maximize $\mathrm{O}_{2}$ transmission and retard water vapor. Since the molecular diameter of water is smaller than that of oxygen, porous membranes that separate gases based on Knudsen diffusion will not work for this application. In fact it is extremely difficult to prevent water transmission through membranes optimized for high $\mathrm{O}_{2}$ permeabilities. Figure 3 shows the Li metal negative electrode from cells discharged in wet air $\left(23{ }^{\circ} \mathrm{C}, 20 \% \mathrm{RH}\right)$ using a Teflon coated fiberglass cloth (TCFC) OSM (left) and without OSM [18]. The $\mathrm{Li}$ is relatively pristine for the cell that used the OSM and completely consumed to form lithium hydroxide in the cell with no OSM.

Practically, it is not necessary for an OSM to be a perfect water vapor barrier for primary applications. However, small amounts of water will react with $\mathrm{Li}$ to form a resistive surface film. Even water concentrations of 200 ppm will increase the Li resistivity, most likely due to thickening of the film on the Li. This exact increase in resistivity is highly dependent on electrolyte salt, electrolyte 
solvent, and the amount of water in the electrolyte [19]. MaxPower has found that selectivities of 2.5 to $5 \mathrm{~mol} \mathrm{O}_{2}$ per mol $\mathrm{H}_{2} \mathrm{O}$ will allow for normal discharge of a primary Li-air cell for at least one week.

Figure 3. Pictures of Li metal negative electrode after cell discharge in humid air for cells using an OSM (left) and with no membrane (right).

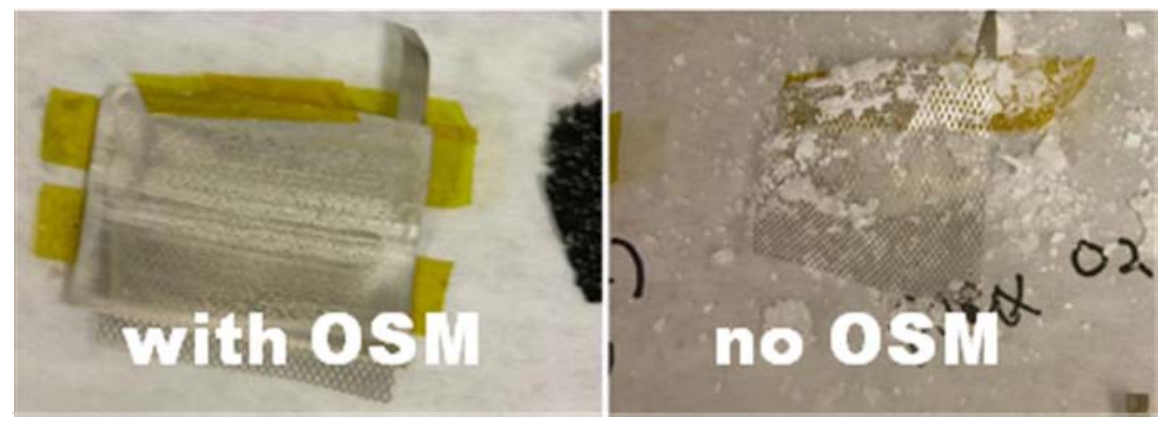

\subsection{No Electrolyte Solvent Permeability}

Read et al. [20] demonstrated increasing the $\mathrm{O}_{2}$ solubilities of a Li-air electrolyte results in increased capacity. However, electrolyte solvents with high $\mathrm{O}_{2}$ solubilities tend to have low viscosities and boiling points and will evaporate quickly [20,21]. Electrolyte evaporation will lead to premature cell failure since $\mathrm{Li}^{+}$in the electrolyte will not be able to reach all of the active carbon reaction sites. Figure 4 shows the evaporation rate for a typical lab cell with and without an OSM [16]. The electrolyte solution used in this study was $1 \mathrm{~mol} \mathrm{dm}^{-3} \mathrm{LiBF}_{4}$ in a $1: 1: 1(\mathrm{o} / \mathrm{v})$ solvent mixture of propylene carbonate (PC), dimethyl carbonate (DMC) and methoxybenzene (MOB). The use of a TCFC OSM reduces the evaporation from approximately $40 \%$ to $2 \%$ over the course of a month, a very acceptable number for continuous operation for primary applications. MaxPower has observed materials with high water vapor permeabilities also have high electrolyte solvent permeabilities. One measure of electrolyte compatibility is to soak the OSM in a given electrolyte for a period of time. Ideally, there would be no mass gain and no swelling of the OSM after removal from the solvent. The actual solvent permeation rate can also be measured according to ASTM F739.

Figure 4. Evaporation rates of a typical electrolyte from a pouch cell with and without an OSM [18].

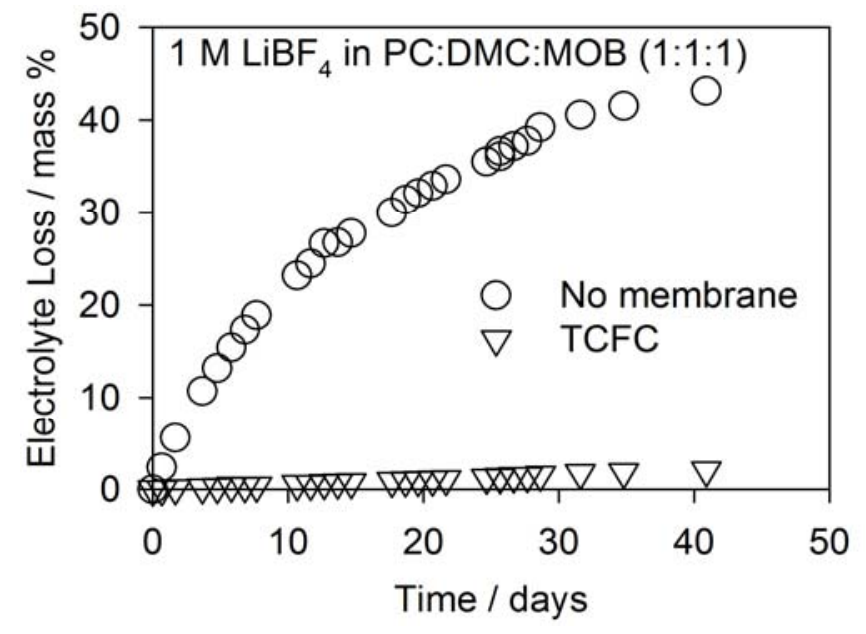




\section{4. $\mathrm{No} \mathrm{CO}_{2}$ Permeability for Secondary Applications}

Carbon dioxide transmission through most OSM materials is often comparable to oxygen where, for example, ratios of $P\left(\mathrm{O}_{2}\right) / P\left(\mathrm{CO}_{2}\right)$ are often less than unity. Carbon dioxide will react with the $\mathrm{Li}_{2} \mathrm{O}_{2}$ (or even $\mathrm{Li}_{2} \mathrm{O}$ ) discharge product to form lithium carbonate $\left(\mathrm{Li}_{2} \mathrm{CO}_{3}\right) \cdot \mathrm{Li}_{2} \mathrm{O}_{2}$ can reversibly evolve $\mathrm{O}_{2}$ during cell charging while $\mathrm{Li}_{2} \mathrm{CO}_{3}$ cannot [22]. McCloskey et al. [23] recently highlighted additional problems with $\mathrm{Li}_{2} \mathrm{CO}_{3}$ formation. Therefore, the OSM, if being used for a rechargeable Li-air battery, must also be an effective $\mathrm{CO}_{2}$ barrier for acceptable cycle life. This is a challenge since materials with high $\mathrm{O}_{2}$ permeabilities tend to also have high $\mathrm{CO}_{2}$ permeabilities [14-16]. However, the actual discharge product does not matter in primary Li-air cells so there is no requirement that the OSM is a $\mathrm{CO}_{2}$ barrier for primary applications [18].

Nitrogen being inert will also have little or no effect on the performance of Li-air cells. It is interesting to note the for materials which exhibit high $\mathrm{O}_{2}$ solubility, $P\left(\mathrm{O}_{2}\right) / P\left(\mathrm{~N}_{2}\right)$ ratios are generally $>1$ thus slightly enriching the relative $\mathrm{O}_{2}$ content over $\mathrm{N}_{2}$.

\section{Basic Materials for Oxygen Selective Membranes}

Oxygen selective membranes can be fabricated or synthesized, or commercially obtained as polymeric films. Two specific (preferred) groups of materials of interest for fabrication of $\mathrm{O}_{2}$-selective membranes in various configurations (gels, polymers, liquids immobilized in a porous inert substrate) include the following.

1. Fluorinated hydrocarbons, polyethers (e.g., Krytox 1506), polyperfloroalkyl oxides, (polyperfloroalkyl amines) have been used membranes based on liquids immobilized in inert substrates [24-26], gels [26,27], and chemically and UV cured polypefloroalkyl oxides [25]. Typical values for $P\left(\mathrm{O}_{2}\right)$ for these membranes approach 1000 Barrer with $P\left(\mathrm{O}_{2}\right) / P\left(\mathrm{H}_{2} \mathrm{O}\right) \sim 3-4$ [25].

2. Polysiloxanes, silicone oils, fluorinated polysiloxanes, and fluorinated polysiloxane copolymer with alkyl methacrylates. Polysiloxanes are thermally stable, exhibit high $\mathrm{O}_{2}$ solubilities, can be used as a liquid immobilized in an inert polymer [25] and thermally or UV cured (vulcanized) to produce a silicon rubber [4,25-27] Typical values for the permeability of $\mathrm{O}_{2}$ in dimethylsilicone rubbers are above 600 Barrer [28,29], and around 100-250 Barrer in methacryloxypropyl terminated polydimethyl contact lenses [30].

Other materials that have been tested as an OSM for Li-air batteries are Melinex 301H (ML) [31-33], high density polyethylene (HDPE) [31], silicalite zeolite or PTFE on nickel foam support [34], silicone oil immobilized in Teflon (PTFE) or nickel/ytrria stabilized zirconia (YSZ)/silicate layered membranes [35], and TCFC with [36] and without [18,36] a silicone adhesive layer. These materials will all be discussed further in below.

\section{Review of Oxygen Selective Membrane Literature}

The two most active groups of researchers developing OSMs are those from MaxPower Inc. and the Pacific Northwest National Laboratory (PNNL). Both groups report different experimental approaches, and a concise summary of these approaches is presented here. 
Zhang et al. [31] tested both ML and HDPE in various sized Li-air cells discharged under ambient conditions. ML (Dupont Teijin Films) is a heat sealable polymer that acted both as the packaging and OSM. It consists of a polyethylene terephthalate (PET) layer and a terephthalate/isophthalate copolyester of ethylene glycol thermal bonding layer. Cells using $20 \mu \mathrm{m}$ ML were able to discharge in $20 \% \mathrm{RH}$ for 33 days at a current density of $0.05 \mathrm{~mA} \mathrm{~cm}^{-2}$ with a taper at the $2 \mathrm{~V}$ cutoff to $0.01 \mathrm{~mA} \mathrm{~cm}$. An optimized pouch cell demonstrated a energy density of $362 \mathrm{Wh} \mathrm{kg}^{-1}$ including package, which is the highest published energy density for a nonaqueous Li-air battery. Cells using $30 \mu \mathrm{m}$ thick ML could not discharge for more than one day due to $\mathrm{O}_{2}$ starvation. The measured $\mathrm{O}_{2}$ permeability of the ML membrane was $\sim 0.02$ Barrer. This value corresponds well with the literature value of PET of 0.01 Barrer [37]. From this permeability value the maximum operating current density for this cell $\sim 0.2 \mu \mathrm{A} \mathrm{cm}^{-2}$ depending on the discharge product using the Equations (4), (7) and (8). The cell packaging was made of ML, so the assumption in Equation (8) that the OSM and air electrode have equal areas is not true in the case. Applying an assumed correction factor that the OSM has an area of 3 times the electrode, the cell should only be able to support a current density of $\sim 0.6 \mu \mathrm{A} \mathrm{cm}{ }^{-2}$. This is two orders of magnitude lower than the actual current density of $50 \mu \mathrm{A} \mathrm{cm}^{-2}$. This discrepancy was attributed to the fact the ML absorbed electrolyte causing the polymer pore size to expand resulting in a higher diffusion coefficient for $\mathrm{O}_{2}$ than in the case of the dry measurement of permeability. Higher $\mathrm{O}_{2}$ diffusion coefficients would result in higher permeabilities via Equation (1). The low current density results in a lower power density of $46 \mathrm{~mW} \mathrm{~g}^{-1}$ that limits the applications of this battery despite the high energy density [38]. HDPE was also tested in this study but the cells did not run well despite the improved $\mathrm{O}_{2}$ permeability of 2 Barrer (membrane from Mid South Extrusion) and 4 Barrer (membrane from Blueridge Films, Inc.). This is most likely because the permeabilities of moisture was also high, so the cells failed because of corrosion of the Li anode [31].

Other OSM membranes developed at PNNL were supported either YSZ/silicate or PTFE on Ni metal foam substrates [34]. Initial experiments on these membranes proved unsuccessful because the porosity of the membranes allowed water vapor to enter the cell via Knudsen diffusion and corrode the $\mathrm{Li}$ anode. The cells performed better when a dense, thin PTFE membrane was spin coated on the substrate. Cells using this membrane were able to discharge for 21 days in air at $20 \% \mathrm{RH}$ at a current density of $0.05 \mathrm{~mA} \mathrm{~cm}^{-2}$, corresponding to capacities of $1,022 \mathrm{mAh} \mathrm{g}^{-1} \mathrm{C}$. The control cell for this experiment discharged under the same conditions with no OSM only demonstrated a capacity of $\sim 300 \mathrm{mAh} \mathrm{g}^{-1} \mathrm{C}$. The actual thickness of the PTFE layer was 1-10 $\mu \mathrm{m}$. The literature value for $\mathrm{O}_{2}$ permeability in Teflon is 4-10 Barrer [39]. Therefore, a $1 \mu \mathrm{m}$ membrane should be able to support a $0.25-2 \mathrm{~mA} \mathrm{~cm}{ }^{-2}$ discharge depending on the actual permeability and discharge product. Thicker membranes would demonstrate lower maximum current densities. However, they did not attempt to test these membranes at higher rates, to our knowledge. Hydrophobic liquids with high $\mathrm{O}_{2}$ solubility were also immobilized in porous membranes to fabricate OSMs [35]. Silicone oils were used as the hydrophobic liquid and several substrates were studied. Silicone oils with higher viscosities performed better, which was attributed to lower water vapor permeation rates. Another possibility is the higher viscosity liquids remained immobilized in the substrate pore better. Cells discharged in $20 \% \mathrm{RH}$ at $0.05 \mathrm{~mA} \mathrm{~cm}^{-2}$ demonstrated capacities between $600-800 \mathrm{mAh} \mathrm{g}^{-1} \mathrm{C}$ using the OSMs and only $250 \mathrm{mAh} \mathrm{g}^{-1}$ with no protection. 
MaxPower, Inc. has been developing higher rate OSMs for Li-air batteries with increased power densities. Early work focused on immobilizing hydrophobic liquids with high $\mathrm{O}_{2}$ solubilities like perfluorotributylamine, perfluorodecalin, and Krytox 1506 into microporous membranes [26]. Other OSMs were fabricated from gelled FMS123 liquid and silicon rubber [26]. One method to immobilize liquids under development is hardening silicone based liquids via UV curing [27]. For example, a polysiloxane-methacrylate copolymer (Gelest) was prepare by dipping a nonwoven polyphenylene sulfide (PPS) membrane into a mixture of methacryloxypropyle polydimethylsiolxanes and photo initiator and exposing to a UV source with 210-315 nm wavelength with an average power of $1,400 \mathrm{~mJ} \mathrm{~cm}^{-2}$ to crosslink the material. Finished OSMs had thicknesses between $330-1,016 \mu \mathrm{m}$. Li-air cell laboratory cells (pouch type, $10 \mathrm{~cm}^{2}$ ) were discharged at a rate of $0.1 \mathrm{~mA} \mathrm{~cm} \mathrm{~cm}^{-2}$ at room temperature and $15 \% \mathrm{RH}$. The cells with thinner OSMs demonstrated improved discharged capacities of $947 \mathrm{mAh} \mathrm{g}^{-1} \mathrm{C}$ compared to $786 \mathrm{mAh} \mathrm{g}^{-1} \mathrm{C}$ for the control cell discharged with no OSM. However, these OSMs were relatively thick limiting $\mathrm{O}_{2}$ flux to the air electrode and thus maximum current density. Thinner OSMs $(76-89 \mu \mathrm{m})$ were fabricated using a RTV-amine (Semicosil 964, Wacker Silicones) coated directly onto an air electrode. The silicone rubber hardened by being moisture cured overnight. Cells discharged with this OSM were able to demonstrate capacities of almost $600 \mathrm{mAh} \mathrm{g}^{-1} \mathrm{C}$ at a high rate of $0.5 \mathrm{~mA} \mathrm{~cm}{ }^{-2}$. This capacity was three times higher than that demonstrated by the control cell discharged under the same conditions with no OSM.

Difficulties reproducibly fabricating thin, pinhole free OSMs led to the investigation of commercially produced membranes. TCFC, mentioned above, was found to work successfully $[18,36]$. The membrane is $70 \mu \mathrm{m}$ thick and has an $\mathrm{O}_{2}$ permeability of 240 Barrer. The selectivity at room temperature from air is $2.5-5$ mole of $\mathrm{O}_{2}$ per mole water vapor depending on the relative humidity. Cells were demonstrated to discharge at rates as high as $0.2 \mathrm{~mA} \mathrm{~cm}{ }^{-2}$, though they failed at rates of $0.5 \mathrm{~mA} \mathrm{~cm}{ }^{-2} .100 \mathrm{~cm}^{2}$ fixtured cells with dramatically reduced electrolyte quantities discharged for more than $2000 \mathrm{mAh} \mathrm{g}^{-1} \mathrm{C}$ at a rate of $0.1 \mathrm{~mA} \mathrm{~cm}^{-2}$ in air at $40-50 \% \mathrm{RH}$. This was evidence in addition to figure 4 that electrolyte evaporation was slowed to acceptable rates. Pouch type laboratory cells $\left(10 \mathrm{~cm}^{2}\right)$ discharged for over $6,000 \mathrm{mAh} \mathrm{g}^{-1} \mathrm{C}$ in air at $20 \% \mathrm{RH}$ at a rate of $0.1 \mathrm{~mA} \mathrm{~cm}{ }^{-2}$.

Sigmund et al. [40,41] has reported on superhydrophobic membranes potentially for Li-air cells based on electrospun Teflon AF2400 though it has not been tested in an operating Li-air cell to our knowledge. Teflon AF2400 is an interesting potential OSM material because of its high $\mathrm{O}_{2}$ permeability of 990 Barrer and excellent solvent resistance [42]. However, these electrospun membranes may not work well in an actual cell due to the highly porous nature of electrospun mats, leading to problems associated with Knudsen diffusion of water vapor described above.

\section{Conclusions}

OSMs have been demonstrated to successfully allow for ambient operation of Li-air batteries in literature. The desired properties of an OSM are high oxygen permeability, no water vapor permeability, no electrolyte solvent permeability, and no carbon dioxide permeability for secondary applications. In practice, no materials exist with no water vapor permeability, however, materials with higher $\mathrm{O}_{2}$ permeation rates (compared to water vapor) can successfully protect the lithium metal anode in a primary Li-air battery. All materials demonstrated as OSMs in the available literature suffer from 
relatively low $\mathrm{O}_{2}$ permeabilities, thus limiting the maximum discharge current density. Therefore novel membranes based on materials with higher $\mathrm{O}_{2}$ permeabilities ( $>100$ Barrer at least) must be developed to increase the power density of Li-air batteries.

\section{Acknowledgments}

We would like to acknowledge the US Army for funding MaxPower Inc.'s primary Li-air program under contract W15P7T-10-C-H602.

\section{References}

1. Atwater, T.G.; Dobley, A. Metal/air batteries. In Linden's Handbook of Batteries, 4th ed.; Reddy, T.B., Ed.; McGraw-Hill Professional: New York, NY, USA, 2010.

2. Abraham, K.M.; Jiang, Z. A polymer electrolyte-based rechargeable lithium/oxygen battery. J. Electrochem. Soc. 1996, 143, 1-5.

3. Kowalczk, I.; Read, J.; Salomon, M. Li-air batteries: A classic example of limitations owing to solubilities. Pure Appl. Chem 2007, 79, 851-860.

4. Crowther, O.; Meyer, B.; Morgan, M.; Salomon, M. Primary Li-air cell development. J. Power Sources 2011, 196, 1498-1502.

5. Crowther, O.; Meyer, B.; Morgan, M.; Salomon, M. Erratum to "primary Li-air cell development”. J. Power Sources 2011, 196, 1498-1502.

6. Bard, A.J.; Parsons, R.; Jordan, J. Standard Potentials in Aqueous Solution; Marcel Dekker: New York, NY, USA, 1995.

7. Christensen, J.; Albertus, P.; Sanchez-Carrera, R.S.; Lohmann, T.; Kozinsky, B.; Liedtke, R.; Ahmed, J. A critical review of Li/air batteries. J. Electrochem. Soc. 2012, 159, R1-R30.

8. Crowther, O.; Salomon, M. Aqueous Li-air $\left(\mathrm{O}_{2}\right)$ systems. In Advanced Lithium Batteries; Scrosati, B., Abraham, K.M., van Shalkwijk, W., Eds.; John Wiley: Hoboken, NJ, USA, 2012, in press.

9. $\mathrm{Fu}, \mathrm{J}$. Superionic conductivity of glass-ceramics in the system $\mathrm{Li}_{2} \mathrm{O}-\mathrm{Al}_{2} \mathrm{O}_{3}-\mathrm{TiO}_{2}-\mathrm{P}_{2} \mathrm{O}_{5}$. Solid State Ionics 1997, 96, 195-200.

10. $\mathrm{Fu}, \mathrm{J}$. Fast $\mathrm{Li}^{+}$ion conducting glass-ceramics in the system $\mathrm{Li}_{2} \mathrm{O}-\mathrm{Al}_{2} \mathrm{O}_{3}-\mathrm{GeO}_{2}-\mathrm{P}_{2} \mathrm{O}_{5}$. Solid State Ionics 1997, 104, 191-194.

11. Fu, J. Lithium Ion Conductive Glass-Ceramics and Electric Cells And Gas Sensors Using the Same. U.S. Patent 6,030,909, October 24, 1997.

12. Visco, S.J.; Katz, B.D; Nimon, Y.S.; de Jonghe, L.C. Protected Active Metal Electrode and Battery Cell Structure with Non-Aqueous Interlayer Architecture. US Patent 7,282,295, 16 October 2007.

13. Scrosati, B.; Garche, J. Lithium batteries: Status, prospects, and future. J. Power Sources 2010, 195, 2419-2430.

14. Battino, R.; Rettich, T.R.; Tominaga, T. The solubility of oxygen and ozone in liquids. J. Phys. Chem. Ref. Data 1983, 12, 163-179.

15. Battino, R. IUPAC Solubility Data Ser. 1984, 7, 1-519. 
16. Dias, A.M.A.; Freire, M.; Coutinho, J.A.P.; Marrucho, I.M. Solubility of oxygen in liquid perfluorocarbons. Fluid Phase Equilib. 2004, 222-223, 325-330.

17. McCloskey, B.D.; Bethune, D.S.; Shelby, R.M.; Girishkumar, G.; Luntz, A.C. Solvent' critical role in nonaqueous lithium-oxygen battery electrochemistry. J. Phys. Chem. Lett. 2011, 2, 1161-1166.

18. Crowther, O.; Keeny, D.; Moureau, D.M.; Meyer, B.; Salomon. M.; Hendrickson, M. Electrolyte optimization for the primary lithium metal air battery using an oxygen selective membrane. J. Power Sources 2012, 202, 347-351.

19. Zaban, A.; Zinigrad, E.; Aurbarch, D. Impedance spectroscopy of li electrodes. 4. A general simple model of the li-solution interphase in polar aprotic systems. J. Phys. Chem. 1996, 100, 3089-3101.

20. Read, J.; Mutolo, K.; Ervin, M.; Behl, W.; Wolfenstine, J.; Driedger, A.; Foster, D. Oxygen transport properties of organic electrolytes and performance of lithium/oxygen battery. J. Electrochem. Soc. 2003, 150, A1351-A1356.

21. Xu, W.; Xiao, J.; Zhang, J.; Wang, D.; Zhang, J.-G. Optimization of nonaqueous electrolyte for primary lithium/air batteries operated in ambient environments. J. Electrochem. Soc. 2009, 156, A773-A779.

22. Freunberger, S.A.; Chen, Y.; Peng, Z.; Griffin, J.M.; Hardwick, L.J.; Bardé, F.; Novák, P; Bruce, P.G. Reactions in rechargeable lithium- $\mathrm{O}_{2}$ battery with alkyl carbonate electrolytes. $J$. Am. Chem. Soc. 2011, 133, 8040-8047.

23. McCloskey, B.D.; Speidel, A.; Scheffler, R.; Miller, D.C.; Viswanathan, V.; Hummelshøj, J.S.; Nørskov, J.K.; Luntz, A.C. Twin problems of interfacial carbonate formation in nonaqueous Li-O ${ }_{2}$ batteries. J. Phys. Chem. Lett. 2012, 3, 997-1001.

24. Goldstein, J.; Korall, M.; Brokman, A. Electrodes for Metal/Air Batteries and Bipolar Metal/Air Batteries Incorporating the Same. US Patent 5,145,752, 8 September 1992.

25. Reynolds, T.A.; Brose, D.J.; Golovin, M.N. Membrane for Selective Transport of Oxygen Over Water Vapor and Metal-Air Electrochemical Cell Including Said Membrane. US Patent 5,985,475, 16 November 1999.

26. Chua, D.; Driedger, A.; Meyer, B.; Morgan, M.; Salomon, M. Protected Lithium-Air Cells by Oxygen-Selective Permeable Cathode Membranes. US Patent 0,177,400, 21 January 2011.

27. Clarke, R. Fluorosiloxane Optical Cladding. US Patent 4,317,616, 2 March 1982.

28. Blume, I.; Schwering, P.J.F.; Mulder, M.H.V.; Smolders, C.A. Vapor sorption and permeation properties of poly(dimethylsiloxane) films. J. Membr. Sci. 1991, 61, 85-97.

29. Zhang, H.; Cloud, A. The permeability characteristics of silicone rubber. In Global Advances in Materials and Process Engineering; In Proceedings of 38th International SAMPE Technical Conference, Dallas, TX, USA, November 2006; Pilato, L.A., Kliger, H.S., Beckwith, S.W., Eds.; Destech Pubns Inc.: Lancaster, PA, USA, 2006.

30. Lai, Y.-C.; Lang, W.; Quinn, E.T.; Ruscio, D.V. Hydrogel Copolymers for Biomedical Devices. US Patent 2006/0142525 A1, 29 June 2006.

31. Zhang, J.-G.; Wang, D.; Xu, W.; Xiao, J.; Williford, R.E. Ambient operation of Li/air batteries. J. Power Sources 2010, 195, pp. 4332-4337. 
32. Wang, D.; Xiao, J.; Xu, W.; Zhang, J.-G. High capacity pouch-type Li-air batteries. J. Electrochem. Soc. 2010, 157, A760-A764.

33. Xiao, J.; Mei, D.; Li, X.; Xu, W; Wang, D.; Graff, G.L.; Bennet, W.D.; Ne, Z.; Saraf, L.V.; Aksay, I.A.; Liu, J.; Zhang, J.-Z. Hierarchically porous graphene as lithium-air battery electrode. Nano Lett. 2011, 11, 5071-5078.

34. Zhang, J.; Xu, W.; Li, X.; Liu, W. Air dehydration membranes for nonaqueous lithium-air batteries. J. Electrochem. Soc. 2010, 157, A940-A946.

35. Zhang, J.; Xu, W.; Liu, W. Oxygen-selective immobilized liquid membranes for operation of lithium-air batteries in ambient air. J. Power Sources 2010, 195, 7438-7444.

36. Crowther, O; Chua, D.; Eppley, W.; Meyer, B.; Salomon M.; Driedger, A.; Morgan, M. Lithium-air cell protective membranes comprising polytetrafluroethylene coated fiberglass cloth. US Patent 2011/0177401 A1, 21 July 2011.

37. Liu, R.Y.F.; Hu, Y.S.; Schiraldi, D.A.; Hiltner, A.; Baer, E. Crystallinity and oxygen transport properties of PET bottle walls. J. Appl. Polymer Sci. 2004, 94, 671-677.

38. Kraytsberg, A.; Ein-Eli, Y. Review on Li-air batteries-opportunities, limitations, and perspective. J. Power Sources 2011, 196, 886-893.

39. Aiba, S.; Ohashi, M.; Huang, S.-Y. Rapid determination of oxygen permeability of polymer membranes. Ind. Eng. Chem. Fundamen. 1968, 7, 497-502.

40. Muthiah, P; Hsu, S.H.; Sigmund, W. Coaxially electrospun PVDF-Teflon AF and Teflon AF-PVDF core-sheath nanofiber mats with superhydrophobic properties. Langmuir 2010, 26, 12483-12487.

41. Scheffler, R.; Bell, N.S.; Sigmund, W. Electrospun Teflon AF fibers for superhydrophobic membranes. J. Mater. Res. 2010, 25, 1595-1600.

42. DuPont ${ }^{\mathrm{TM}}$ Teflon ${ }^{\circledR}$ Afamorphous Fluoropolymers; DuPont Fluoroproducts: Wilmington, DE, USA, 2012. Available online: http://www2.dupont.com/Teflon_Industrial/en_US/assets/ downloads/h44587.pdf (accessed on 12 April 2012).

(C) 2012 by the authors; licensee MDPI, Basel, Switzerland. This article is an open access article distributed under the terms and conditions of the Creative Commons Attribution license (http://creativecommons.org/licenses/by/3.0/). 